
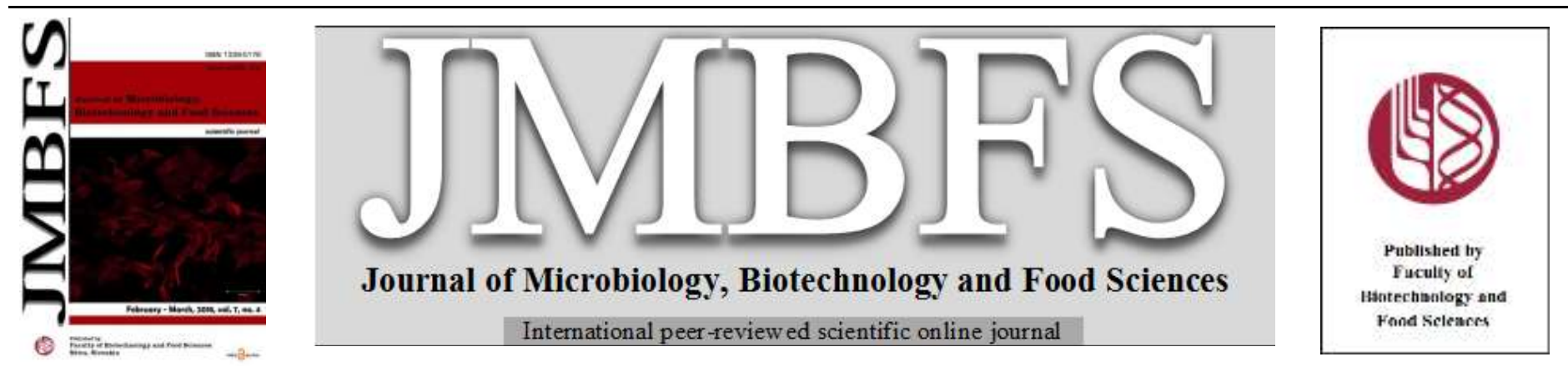

\title{
DETERMINATION OF MICRO AND TRACE ELEMENTS OF COMMERCIAL BEERS
}

\section{Loránd Alexa*, Andrea Kántor, Béla Kovács, Nikolett Czipa}

\author{
Address(es): Loránd Alexa, \\ *Institute of Food Science, Faculty of Agricultural and Food Sciences and Environmental Management, University of Debrecen, H-4032 Böszörményi street 138, \\ Debrecen, Hungary. Tel: +36 309211716 .
}

*Corresponding author: alexal@agr.unideb.hu

doi: $10.15414 / j m b f s .2018 .7 .4 .432-436$

\section{ARTICLE INFO}

Received 19. 10. 2017

Revised 24. 11. 2017

Accepted 1. 12. 2017

Published 1. 2. 2018

Regular article

oren $\partial$ access

\begin{abstract}
In the present paper, a risk analysis of beer's element content has been carried out. $\mathrm{Al}, \mathrm{As}, \mathrm{Ba}, \mathrm{Cd}, \mathrm{Co}, \mathrm{Cr}, \mathrm{Cu}, \mathrm{Fe}, \mathrm{Mo}, \mathrm{Mn}, \mathrm{Ni}, \mathrm{Se}, \mathrm{Sr}$, $\mathrm{Pb}$ and $\mathrm{Zn}$ were determined by Inductively Coupled Plasma Mass Spectrometry (ICP-MS) in 24 beer samples produced by different breweries. Samples could be originated from Hungary, Belgium, the Czech Republic, Germany and Austria, and the set consisted of 4 types of beer: pale barley, dark barley, pale wheat and dark wheat samples. It appeared that Mn was the most abundant among the analysed elements, followed by $\mathrm{Sr}$, and $\mathrm{Al}$, and $\mathrm{Co}$, $\mathrm{Se}$ and $\mathrm{Cr}$ could be found in the lowest concentrations, except for those which were present in a concentration lower than LoD.

The statistical analysis showed that barley and wheat beers could be differentiated according to their $\mathrm{Mn}$ and $\mathrm{Cu}$ content, but to separate all of the groups analysed further investigations and more samples are needed.

$\mathrm{A}$ risk assessment for $\mathrm{Al}, \mathrm{Cu}$ and $\mathrm{Zn}$ has also been performed for the analysed samples. The results showed that none of these elements could have any adverse effect on our health. The assessment of other toxic elements was not needed, because their concentrations were
\end{abstract} under LoD, or their PTDI values have been withdrawn by WHO JECFA.

Keywords: Beer, element, differentiation, risk assessment

\section{INTRODUCTION}

Beer is an extremely popular drink consumed all around the world, even in countries where the production and consumption of alcoholic beverages are not traditional (Alcázar et al., 2002). Beer consumption after the millennium has reached 1,2 billion $\mathrm{hl}$, and it is still growing. For instance, in countries with developed beer culture the consumption of beer exceeds 100 1/year/capita (FAO, 2009). This drink is produced by the alcoholic fermentation of yeasts, which transform carbohydrates found in wort to ethyl alcohol and $\mathrm{CO}_{2}$. In most cases wort can be originated from barley malt, but other cereals can also be used as raw materials (Gama et al., 2017). It also contains hop, and other substances in some cases. Besides beer's various and often really healthy composition, we also have to notice that it could contain elements which could have an adverse effect on the consumers' health. These contaminants are not intentionally added to food in general. They could contaminate the raw materials on the fields as a result of environmental pollution, but these elements can also appear later during the production and distribution (Donadini et al., 2008). For instance, cereals could get contaminated by different kinds of mycotoxins (aflatoxins, DON, fumonisins, etc.) (Pascari et al., 2018), or the usage of low quality cans could increase the concentration of $\mathrm{Cd}$ (Mena et al., 1996). In this study, the concentration of $\mathrm{Al}$, $\mathrm{As}, \mathrm{Ba}, \mathrm{Cd}, \mathrm{Co}, \mathrm{Cr}, \mathrm{Cu}, \mathrm{Fe}, \mathrm{Mo}, \mathrm{Mn}, \mathrm{Ni}, \mathrm{Se}, \mathrm{Sr}, \mathrm{Pb}$ and $\mathrm{Zn}$ were measured by Inductively Coupled Plasma Mass Spectrometry (ICP-MS) in 24 beer samples, then a risk analysis has been performed for the elements mentioned above. The aim of the research was to evaluate micro and trace element contents of beer, and to search for relations between beer types and element concentrations, and to separate different beer types according to that. It was also our goal to investigate whether these elements can be found in a hazardous concentration in the samples analysed.

\section{MATERIAL AND METHODS}

\section{Samples}

Twenty-four beer samples purchased from local stores were analysed. This research has been promoted to identify the risk of beer consumption in general, this is why the analysis of different beer types with different origin was reasonable. Samples were produced by using malt prepared from two cereals: barley (Hordeum vulgare convar. distichon) and wheat (Triticum aestivum). Both test groups contained pale and dark beer samples. Types of the samples were the following: pale barley samples (No. 1-9), dark barley samples (No. 10-17), pale wheat samples (No. 18-22), dark wheat samples (No. 23-24). The origin of these beer samples is presented in Table 2 and Table 3.

\section{Determination of element contents}

The determination of element concentrations was carried out according to the method of Kovács et al. (1996), which had been slightly modified because of the characteristics of the samples used. After decarbonation of beer samples by using ultrasonic water bath (Bandelin Sonorex Digital DT 255H, Germany), $5 \mathrm{ml}$ of nitric acid $(69 \% \mathrm{v} / \mathrm{v}$; VWR International Ltd., Radnor, USA) was added to $20 \mathrm{ml}$ of each sample, then samples were allowed to stand overnight. Next morning, another $5 \mathrm{ml}$ of nitric acid was added at a speed of $1 \mathrm{ml} / \mathrm{h}$. Then the samples were pre-digested at $60^{\circ} \mathrm{C}$ for $30 \mathrm{~min}$. After cooling, $3 \mathrm{ml}$ hydrogen-peroxide $(30 \%$ $\mathrm{v} / \mathrm{v}$; VWR International Ltd., Radnor, USA) was added to the samples, and then samples were digested at $120^{\circ} \mathrm{C}$ for $90 \mathrm{~min}$. After digestion, ultrapure water produced by a Milli-Q water purification system (Millipore SAS, Molsheim, France) was added to volume samples up to $50 \mathrm{ml}$. After filtration (qualitative filter papers - Sartorius Stedim, Biotech S.A., Gottingen, Germany) the determination of microelements was carried out by using ICP-MS (Inductively Coupled Plasma Mass Spectrometry) (Thermo Scientific XSeries 2, Bremen, Germany). List of the analysed isotopes and the limits of detection are shown in Table 1 .

\section{Statistical analysis}

All analytical analysis was carried out in triplicate. Results were described by using general terms such as mean, standard deviation, minimum and maximum values, and One-Way ANOVA (LSD: Least Significant Difference), Linear Discriminant Analysis (LDA) and Independent Samples Test has been performed. For the statistical analysis SPSS for Windows (version 13, SPSS Inc. Chicago, Illinois, USA) has been used. 
Table 1 Analysed elements, isotope values and the limits of detection

\begin{tabular}{lcc}
\hline Element & Isotope & LoD $\left(\boldsymbol{\mu} \mathbf{~ I ~ I}^{\mathbf{1}}\right)$ \\
\hline $\mathrm{Al}$ & 27 & 39.9 \\
\hline $\mathrm{As}$ & 75 & 1.19 \\
\hline $\mathrm{Ba}$ & 137 & 0.65 \\
\hline $\mathrm{Cd}$ & 111 & 0.19 \\
\hline $\mathrm{Co}$ & 59 & 0.20 \\
\hline $\mathrm{Cr}$ & 52 & 3.36 \\
\hline $\mathrm{Cu}$ & 65 & 1.28 \\
\hline $\mathrm{Fe}$ & 56 & 77.4 \\
\hline $\mathrm{Mo}$ & 95 & 1.21 \\
\hline $\mathrm{Mn}$ & 55 & 3.44 \\
\hline $\mathrm{Ni}$ & 60 & 2.92 \\
\hline $\mathrm{Se}$ & 78 & 1.25 \\
\hline $\mathrm{Sr}$ & 88 & 1.09 \\
\hline $\mathrm{Pb}$ & 206 & 0.93 \\
\hline $\mathrm{Zn}$ & 66 & 19.6
\end{tabular}

\section{Health risk assessment}

In this study, we determined the risk of beer consumption calculated with 60 and $90 \mathrm{~kg}$ body weight and 0.51 beer consumption. The risk value was determined with the following equations:
Risk $=\frac{\text { tolerable daily intake }}{\text { average daily intalke }}$

Tolerable daily intake

$=$ PTDI (provisional tolerable daily intake $\mathrm{x}$ body weight) Average daily intake $=$ element concentration of beer $\mathrm{x}$ daily consumption If the value is lower than 1, it means risk, between 1 and 10 the risk is possible and above 10 the risk is negligible.

\section{RESULTS AND DISCUSSION}

\section{Element concentrations}

$\mathrm{Ba}, \mathrm{Co}, \mathrm{Cr}, \mathrm{Mo}, \mathrm{Mn}, \mathrm{Ni}, \mathrm{Se}$ and $\mathrm{Sr}$ concentrations of the samples are shown in Table 2. Among these elements, Mn was the most abundant with an average concentration of $126 \mu \mathrm{g} \mathrm{l}^{-1}$, ranged from $41.0 \pm 2.3$ to $260 \pm 9 \mu \mathrm{g} \mathrm{l}^{-1}$. The concentration of this element was followed closely by $\mathrm{Sr}$ with an average of 123 $\mu \mathrm{g} \mathrm{l^{-1 }}$. The average concentrations of the other analysed elements were much lower, those were the following in decreasing order: $\mathrm{Ba}\left(23.1 \mu \mathrm{g} \mathrm{l}^{-1}\right)$, Mo $(8.54$ $\left.\mu \mathrm{g} \mathrm{l}^{-1}\right)$, Ni $\left(8.02 \mu \mathrm{g} \mathrm{l}^{-1}\right), \mathrm{Cr}\left(3.98 \mu \mathrm{g} \mathrm{l}^{-1}\right)$, Se $\left(2.80 \mu \mathrm{g} \mathrm{l}^{-1}\right)$ and Co $\left(0,270 \mu \mathrm{g} \mathrm{l}^{-1}\right)$ According to these results, $\mathrm{Ni}$ concentration was under the limit of detection in 8 samples, while the concentration of Se could not be measured in 13 of the samples for the same reason.

Table $2 \mathrm{Ba}, \mathrm{Co}, \mathrm{Cr}, \mathrm{Mo}, \mathrm{Mn}, \mathrm{Ni}, \mathrm{Se}$ and $\mathrm{Sr}$ concentrations of the analysed samples

\begin{tabular}{|c|c|c|c|c|c|c|c|c|c|}
\hline \multirow{2}{*}{ Sample } & \multirow{2}{*}{ Origin } & \multicolumn{8}{|c|}{ Concentration $\left(\mu \mathrm{g} \mathrm{l}^{-1}\right)$} \\
\hline & & $B a$ & Co & $\mathrm{Cr}$ & $M o$ & $M n$ & $\mathrm{Ni}$ & $\mathrm{Se}$ & $S r$ \\
\hline 1 & Belgium & $18.0 \pm 1.8$ & $0.256 \pm 0.035$ & $1.19 \pm 0.08$ & $18.3 \pm 0.5$ & $97.7 \pm 6.7$ & $10.0 \pm 0.4$ & $2.74 \pm 0.43$ & $143 \pm 3$ \\
\hline 2 & Hungary & $18.6 \pm 0.2$ & $0.325 \pm 0.027$ & $1.13 \pm 0.09$ & $8.12 \pm 0.14$ & $86.5 \pm 0.8$ & $11.2 \pm 0.7$ & $2.46 \pm 0.06$ & $119 \pm 1$ \\
\hline 3 & Hungary & $37.1 \pm 0.6$ & $0.219 \pm 0.015$ & $2.35 \pm 0.06$ & $2.90 \pm 0.06$ & $67.7 \pm 0.8$ & $<\mathrm{LoD}$ & $<\mathrm{LoD}$ & $133 \pm 1$ \\
\hline 4 & Hungary & $22.3 \pm 1.7$ & $0.169 \pm 0.018$ & $2.12 \pm 0.13$ & $1.73 \pm 0.01$ & $57.8 \pm 3.8$ & $<\mathrm{LoD}$ & $<\mathrm{LoD}$ & $88.0 \pm 6.0$ \\
\hline 5 & Hungary & $14.2 \pm 0.2$ & $0.250 \pm 0.017$ & $1.07 \pm 0.11$ & $4.42 \pm 0.09$ & $46.7 \pm 0.9$ & $<\mathrm{LoD}$ & $<\mathrm{LoD}$ & $50.7 \pm 0.1$ \\
\hline 6 & Czech Republic & $17.6 \pm 1.7$ & $0.225 \pm 0.009$ & $9.36 \pm 0.11$ & $6.83 \pm 0.06$ & $64.2 \pm 2.1$ & $<\mathrm{LoD}$ & $2.56 \pm 0.19$ & $108 \pm 1$ \\
\hline 7 & Czech Republic & $26.1 \pm 2.6$ & $0.350 \pm 0.030$ & $4.19 \pm 0.04$ & $5.26 \pm 0.11$ & $90.8 \pm 2.8$ & $6.12 \pm 0.11$ & $<$ LoD & $106 \pm 2$ \\
\hline 8 & Hungary & $20.2 \pm 0.2$ & $0.257 \pm 0.018$ & $3.38 \pm 0.00$ & $3.04 \pm 0.16$ & $147 \pm 1$ & $10.7 \pm 0.9$ & $3.84 \pm 0.30$ & $163 \pm 1$ \\
\hline 9 & Hungary & $9.95 \pm 1.07$ & $0.181 \pm 0.000$ & $1.90 \pm 0.10$ & $8.34 \pm 0.0$ & $41.0 \pm 2.3$ & $<\mathrm{LoD}$ & $<\mathrm{LoD}$ & $82.3 \pm 6.4$ \\
\hline 10 & Belgium & $22.3 \pm 0.4$ & $0.313 \pm 0.009$ & $1.28 \pm 0.09$ & $17.6 \pm 0.6$ & $122 \pm 6$ & $5.33 \pm 0.01$ & $2.65 \pm 0.22$ & $178 \pm 9$ \\
\hline 11 & Hungary & $25.7 \pm 0.8$ & $0.375 \pm 0.009$ & $0.919 \pm 0.098$ & $14.5 \pm 0.4$ & $122 \pm 1$ & $6.15 \pm 0.51$ & $2.44 \pm 0.15$ & $148 \pm 1$ \\
\hline 12 & Czech Republic & $17.7 \pm 1.6$ & $0.213 \pm 0.026$ & $2.44 \pm 0.20$ & $6.74 \pm 0.52$ & $87.4 \pm 6.1$ & $<\mathrm{LoD}$ & $<\mathrm{LoD}$ & $100 \pm 7$ \\
\hline 13 & Hungary & $25.0 \pm 0.0$ & $0.213 \pm 0.009$ & $5.43 \pm 0.11$ & $12.9 \pm 0.9$ & $159 \pm 6$ & $7.88 \pm 0.22$ & $3.90 \pm 0.20$ & $95.0 \pm 4.1$ \\
\hline 14 & Czech Republic & $27.8 \pm 2.6$ & $0.356 \pm 0.015$ & $13.5 \pm 0.2$ & $8.05 \pm 0.76$ & $142 \pm 7$ & $7.75 \pm 0.23$ & $<\mathrm{LoD}$ & $143 \pm 10$ \\
\hline 15 & Hungary & $23.1 \pm 0.7$ & $0.300 \pm 0.001$ & $16.7 \pm 0.4$ & $15.1 \pm 0.2$ & $122 \pm 1$ & $4.84 \pm 0.39$ & $2.10 \pm 0.10$ & $142 \pm 1$ \\
\hline 16 & Czech Republic & $23.6 \pm 1.7$ & $0.356 \pm 0.000$ & $4.87 \pm 0.17$ & $9.56 \pm 0.09$ & $103 \pm 8$ & $5.97 \pm 0.28$ & $<\mathrm{LoD}$ & $113 \pm 1$ \\
\hline 17 & Czech Republic & $28.6 \pm 1.9$ & $0.481 \pm 0.037$ & $4.90 \pm 0.50$ & $9.97 \pm 0.47$ & $85.0 \pm 2.6$ & $5.39 \pm 0.38$ & $<\mathrm{LoD}$ & $169 \pm 12$ \\
\hline 18 & Germany & $18.4 \pm 0.4$ & $0.194 \pm 0.000$ & $1.68 \pm 0.07$ & $7.59 \pm 0.14$ & $225 \pm 2$ & $13.7 \pm 0.9$ & $<\mathrm{LoD}$ & $72.3 \pm 1.8$ \\
\hline 19 & Germany & $24.7 \pm 1.5$ & $0.206 \pm 0.015$ & $2.18 \pm 0.16$ & $5.37 \pm 0.44$ & $215 \pm 11$ & $8.76 \pm 0.45$ & $2.31 \pm 0.16$ & $212 \pm 7$ \\
\hline 20 & Czech Republic & $21.5 \pm 0.4$ & $0.288 \pm 0.009$ & $2.16 \pm 0.04$ & $2.74 \pm 0.01$ & $169 \pm 1$ & $7.28 \pm 0.53$ & $2.31 \pm 0.15$ & $145 \pm 1$ \\
\hline 21 & Austria & $19.5 \pm 1.1$ & $0.282 \pm 0.018$ & $2.34 \pm 0.16$ & $12.3 \pm 0.4$ & $260 \pm 9$ & $7.62 \pm 0.44$ & $3.48 \pm 0.22$ & $84.5 \pm 3.2$ \\
\hline 22 & Germany & $39.9 \pm 2.6$ & $0.188 \pm 0.016$ & $1.13 \pm 0.11$ & $6.06 \pm 0.30$ & $117 \pm 5$ & $9.74 \pm 0.49$ & $<\mathrm{LoD}$ & $103 \pm 7$ \\
\hline 23 & Germany & $23.5 \pm 1.9$ & $0.238 \pm 0.097$ & $3.56 \pm 0.27$ & $7.92 \pm 0.64$ & $167 \pm 6$ & $<\mathrm{LoD}$ & $<\mathrm{LoD}$ & $173 \pm 16$ \\
\hline 24 & Germany & $26.4 \pm 0.7$ & $0.238 \pm 0.009$ & $5.64 \pm 0.37$ & $9.81 \pm 0.11$ & $229 \pm 4$ & $<\mathrm{LoD}$ & $<\mathrm{LoD}$ & $81.5 \pm 1.9$ \\
\hline
\end{tabular}

Table 3 contains the concentration of another 7 elements: Al, As, Cd, Cu, Fe, Pb and $\mathrm{Zn}$. For these elements, a risk assessment has also been performed according to their Provisional Tolerable Intake values determined by WHO JECFA, except for As and $\mathrm{Pb}$, because in their case PTDI values have been withdrawn. As for $\mathrm{Cd}$ and $\mathrm{Fe}$ content, none of the analysed samples had higher concentrations than the limit of detection. The concentration of $\mathrm{Al}$ was lower than LoD in 16 samples, such as $\mathrm{Pb}$ concentrations in case of 5 samples. Out of these elements, the average of $\mathrm{Al}$ concentrations was the highest $\left(106 \mu \mathrm{g} \mathrm{l}^{-1}\right)$, followed by $\mathrm{Cu}$ $\left(81.3 \mu \mathrm{g} \mathrm{l}^{-1}\right)$ and $\mathrm{Zn}\left(49.6 \mu \mathrm{g}^{-1}\right)$, but notice that many of these samples did not contain enough $\mathrm{Al}$ to detect. The concentration of $\mathrm{Pb}$ and $\mathrm{As}$ were much lower than the elements mentioned above $\left(4.75,3.99 \mathrm{~g}^{-1}\right)$.

While comparing all of the element contents, it appears that these beer samples contained $\mathrm{Mn}$ in the highest concentration in general, followed by $\mathrm{Sr}$ and $\mathrm{Al}$, and they had the lowest concentrations of $\mathrm{Co}$, Se and $\mathrm{Cr}$, except for the elements which could be found in a concentration lower than $\operatorname{LoD}(\mathrm{Cd}, \mathrm{Fe})$. These low concentrations can be justified by comparing them to the results of other authors. In the study of Mena et al. (1996), the mean value of Cd concentrations had been $0.21 \mu \mathrm{g} \mathrm{l}^{-1}$, which is almost the limit of detection we have established. What is more, the article mentions that higher $\mathrm{Cd}$ concentrations could be determined in canned beers, and the improper composition of the cans could increase $\mathrm{Cd}$ concentrations. In the thesis of a Hungarian researcher, Beáta Hegyesné Vecseri (2004), Cd could not be found over LoD (of our method) in the analysed beer samples, and the mean value of Fe concentrations $\left(70 \mu \mathrm{g}^{-1}\right)$ was also under our LoD value.

\section{Differentiation of the analysed beer types according to their element contents}

First, the results were described by using statistical terms like mean, standard deviation, minimum and maximum values.

To start separation of the analysed beer types, Independent Samples Test has been performed first. The test showed that barley and wheat beers could be differentiated by their $\mathrm{Cu}$ and $\mathrm{Mn}$ concentrations: in case of $\mathrm{Cu}, \mathrm{P}$-value was 0.001 , and for Mn, P-value was 0.000 . 
Table $3 \mathrm{Al}, \mathrm{As}, \mathrm{Cd}, \mathrm{Cu}, \mathrm{Fe}, \mathrm{Pb}$ and $\mathrm{Zn}$ content of the analysed samples

\begin{tabular}{|c|c|c|c|c|c|c|c|c|}
\hline \multirow{2}{*}{ Sample } & \multirow{2}{*}{ Origin } & \multicolumn{7}{|c|}{ Concentration $\left(\mu \mathrm{g} \mathrm{I}^{-1}\right)$} \\
\hline & & $A l$ & As & $C d$ & Cu & $\mathrm{Fe}$ & $P b$ & $Z n$ \\
\hline 2 & Hungary & $153 \pm 7$ & $5.26 \pm 0.08$ & $<\mathrm{LoD}$ & $70.4 \pm 5.9$ & $<\mathrm{LoD}$ & $3.97 \pm 0.41$ & $30.3 \pm 2.4$ \\
\hline 4 & Hungary & $<\mathrm{LoD}$ & $2.80 \pm 0.20$ & $<\mathrm{LoD}$ & $83.4 \pm 5.0$ & $<\mathrm{LoD}$ & $4.14 \pm 0.38$ & $29.1 \pm 2.5$ \\
\hline 5 & Hungary & $\angle \mathrm{LoD}$ & $2.44 \pm 0.15$ & $<\mathrm{LoD}$ & $96.2 \pm 7.1$ & $<\mathrm{LoD}$ & $4.38 \pm 0.35$ & $28.3 \pm 2.6$ \\
\hline 6 & Czech Republic & $<\mathrm{LoD}$ & $4.68 \pm 0.18$ & $<\mathrm{LoD}$ & $91.3 \pm 2.1$ & $<\mathrm{LoD}$ & $3.85 \pm 0.28$ & $23.9 \pm 1.1$ \\
\hline 9 & Hungary & $<\mathrm{LoD}$ & $3.92 \pm 0.04$ & $<\mathrm{LoD}$ & $71.5 \pm 6.3$ & $<\mathrm{LoD}$ & $\angle \mathrm{LoD}$ & $27.8 \pm 1.2$ \\
\hline 10 & Belgium & $<\mathrm{LoD}$ & $4.20 \pm 0.33$ & $<\mathrm{LoD}$ & $100 \pm 7$ & $<\mathrm{LoD}$ & $4.98 \pm 0.37$ & $53.6 \pm 4.6$ \\
\hline 11 & Hungary & $<\mathrm{LoD}$ & $4.80 \pm 0.60$ & $<\mathrm{LoD}$ & $62.7 \pm 4.6$ & $<\mathrm{LoD}$ & $4.71 \pm 0.26$ & $45.9 \pm 4.5$ \\
\hline 12 & Czech Republic & $<\mathrm{LoD}$ & $2.63 \pm 0.09$ & $<\mathrm{LoD}$ & $83.7 \pm 7.4$ & $<\mathrm{LoD}$ & $5.77 \pm 0.50$ & $73.7 \pm 5.21$ \\
\hline 13 & Hungary & $74.9 \pm 6.9$ & $3.18 \pm 0.25$ & $<\mathrm{LoD}$ & $106 \pm 10$ & $<\mathrm{LoD}$ & $5.37 \pm 0.39$ & $98.1 \pm 5.2$ \\
\hline 18 & Germany & $<\mathrm{LoD}$ & $2.73 \pm 0.11$ & $<\mathrm{LoD}$ & $96.4 \pm 6.1$ & $<\mathrm{LoD}$ & $4.97 \pm 0.42$ & $66.9 \pm 1.2$ \\
\hline 19 & Germany & $\angle \mathrm{LoD}$ & $2.09 \pm 0.19$ & $<\mathrm{LoD}$ & $70.2 \pm 4.1$ & $<\mathrm{LoD}$ & $3.90 \pm 0.05$ & $45.3 \pm 3.8$ \\
\hline 20 & Czech Republic & $\angle \mathrm{LoD}$ & $3.26 \pm 0.20$ & $<\mathrm{LoD}$ & $27.3 \pm 2.2$ & $<\mathrm{LoD}$ & $<\mathrm{LoD}$ & $44.2 \pm 2.7$ \\
\hline 21 & Austria & $<\mathrm{LoD}$ & $1.95 \pm 0.10$ & $<\mathrm{LoD}$ & $57.2 \pm 0.6$ & $<\mathrm{LoD}$ & $\angle \mathrm{LoD}$ & $79.1 \pm 4.7$ \\
\hline 22 & Germany & $\angle \mathrm{LoD}$ & $1.82 \pm 0.10$ & $<\mathrm{LoD}$ & $46.8 \pm 4.1$ & $<\mathrm{LoD}$ & $<\mathrm{LoD}$ & $72.4 \pm 5.3$ \\
\hline 23 & Germany & $<\mathrm{LoD}$ & $3.23 \pm 0.12$ & $<\mathrm{LoD}$ & $51.2 \pm 4.0$ & $<\mathrm{LoD}$ & $<\mathrm{LoD}$ & $37.9 \pm 3.9$ \\
\hline 24 & Germany & $<\mathrm{LoD}$ & $8.31 \pm 0.21$ & $<\mathrm{LoD}$ & $83.7 \pm 2.1$ & $<\mathrm{LoD}$ & $4.24 \pm 0.22$ & $44.7 \pm 2.1$ \\
\hline
\end{tabular}

For the division of the 4 groups mentioned before, One-Way ANOVA (LSD) has been used, because the variance of the variables had been homogeneous. The results showed that there are significant differences between beer types in some of their element concentrations. In case of As, pale barley and pale wheat samples showed significant difference $(\mathrm{P}$ value $=0.039)$, such as pale wheat and dark wheat samples $(\mathrm{P}$ value $=0.034)$. Pale barley and pale wheat beers could also be divided according to their $\mathrm{Cu}$ content $(\mathrm{P}$ value $=0.006)$, just like dark barley and pale wheat samples $(\mathrm{P}$ vale $=0.006)$. Due to the $\mathrm{Zn}$ concentrations, the difference between pale barley and dark barley, such as pale barley and pale wheat samples could be statistically verified $(P$ value $=0.007$ and 0.017$)$. The test also showed that there was a difference in the pale barley and dark barley, and dark barley and pale wheat in their Co concentrations ( $\mathrm{P}$ value $=0.034$ and 0.027). Mo and Mn concentrations also showed significant difference. As for Mo, pale barley could be separated from dark barley samples $(\mathrm{P}$ value $=0.018$ ), what is more, there was a significant difference between dark barley and pale wheat samples also $(\mathrm{P}$ value $=0.049$ ). According to the concentrations of $\mathrm{Mn}$, pale barley samples showed difference from every other category $(\mathrm{P}$ value $=0.037$, 0.000 and 0.000), furthermore dark barley samples also showed significant difference from pale and dark wheat samples $(\mathrm{P}$ value $=0.001$ and 0.012$)$.

After carrying the LSD test out, a Linear Discriminant Analysis (LDA) has also been performed, its results can be seen in Figure 1.

Canonical Discriminant Functions

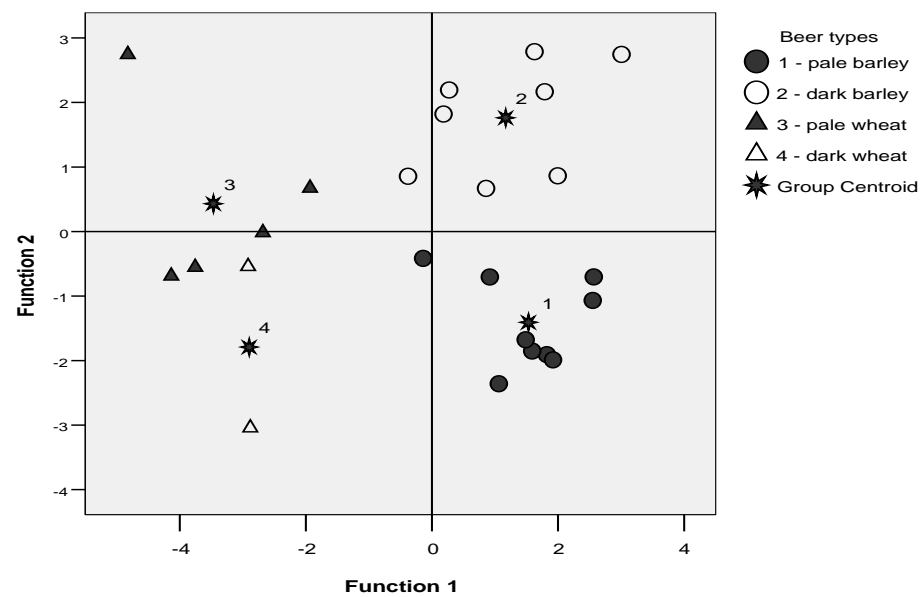

Figure 1 Linear Discriminant Analysis of different beer types

According to the LSD test, differences were found among the beer types analysed due to the microelement concentrations. Because of this, LDA analysis was carried out to verify the distinction of different beer types. The grouping variables were the beer types and the independent variables were the elements (As, $\mathrm{Cu}, \mathrm{Zn}, \mathrm{Co}, \mathrm{Mo}$ and $\mathrm{Mn}$ ). Three discriminant functions were determined, with eigenvalue from 3.16 for the first to 0.144 for the last. The first function explained $84.5 \%$, the second one $71.4 \%$ and the last one $16.8 \%$ of the variance of dependent variables. In the first function the group of pale barley beers showed the highest centroid (1.53) followed by group of dark barley beers (1.17), dark wheat beers $(-2.90)$ and pale wheat beers $(-3.47)$. In the second dimension the highest centroid was determined in the group of dark barley beers (1.76) followed by pale wheat beers $(0.43)$, pale barley beers $(-1.41)$ and dark wheat beers (1.79). Therefore, the dark barley beers showed high centroid in both dimensions, the pale barley showed high value in the first dimension, however, in the second dimension this value was low. Pale wheat and dark wheat beers showed lower centroids in both dimensions. According to the cross validation, in case of pale barley beers the number of correctly categorized cases was $8(88,9 \%)$, because one sample moved into dark barley beer group. In case of dark barley beers this number is $7(87,5 \%)$, because one sample moved into pale barley beer group. In case of pale wheat beers, the number of correctly categorized cases was only two $(40 \%)$, because two samples moved into dark barley beer group and two samples moved into dark wheat beer group. In case of dark wheat beer this number was only one $(50 \%)$, because one sample moved into pale wheat beer group. Overall $75,0 \%$ of cross-validated grouped cases was correctly classified.

\section{Risk assessment}

In this study, a risk assessment for beer's microelement contents has been done to determine whether temperate consumption of beer could have any adverse effect on human health and life or not. To manage that, the database of WHO JECFA (Joint FAO/WHO Expert Committee on Food Additives) has been used, which contains the PTDI values of different metals. These values are shown in Table 4. 
Table 4 PTMI, PTWI and PTDI values of metals determined by WHO JECFA

\begin{tabular}{|c|c|c|c|c|c|}
\hline Element & Year of determination & PTMI & PTWI & PTDI & Reference \\
\hline$A l$ & 2011 & $8 \mathrm{mg} \mathrm{kgbw}^{-1}$ & $2 \mathrm{mg} \mathrm{kgbw}^{-1}$ & $0,267 \mathrm{mg} \mathrm{kgbw}^{-1}$ & TRS 996-JECFA 74/7 \\
\hline As & 2011 & & withdrawn & & TRS 959-JECFA 72 \\
\hline$C d$ & 2013 & $25 \mu \mathrm{ggbw}^{-1}$ & $6,25 \mu \mathrm{g} \mathrm{kgbw}^{-1}$ & $0,833 \mu \mathrm{g} \mathrm{kgbw}^{-1}$ & TRS 983 JECFA 77 \\
\hline $\boldsymbol{C u}$ & 1982 & $15 \mathrm{mg} \mathrm{kgbw}^{-1}$ & $3,5 \mathrm{mg} \mathrm{kgbw}^{-1}$ & $0,5 \mathrm{mg} \mathrm{kgbw}^{-1}$ & TRS 683-JECFA 26/31 \\
\hline$F e$ & 1983 & $24 \mathrm{mg} \mathrm{kgbw}^{-1}$ & $5,6 \mathrm{mg} \mathrm{kgbw}^{-1}$ & $0,8 \mathrm{mg} \mathrm{kgbw}^{-1}$ & TRS 696-JECFA 27/29 \\
\hline$P b$ & 2011 & & withdrawn & & TRS 960-JECFA 73 \\
\hline$Z n$ & 1982 & $9-30 \mathrm{mg} \mathrm{kgbw}^{-1}$ & $2,1-7 \mathrm{mg} \mathrm{kgbw}^{-1}$ & $0,3-1 \mathrm{mg} \mathrm{kgbw}^{-1}$ & TRS 683-JECFA 26/32 \\
\hline
\end{tabular}

According to the values showed in Table 4, PTDI values can also be calculated 1), which is shown by Table 6. Empty cells represent samples which have not for people with a body weight of 60 and $90 \mathrm{~kg}$, which are presented in Table $5 . \quad$ contained the analysed element in higher concentration than LoD.

The next step was the calculation of the element contents of one glass of beer $(0,5$

Table 5 PTDI values for 60 and $90 \mathrm{~kg}$ body weight

\begin{tabular}{|c|c|c|}
\hline \multirow{2}{*}{ Element } & PTDI values for a body weight of $60 \mathrm{~kg}$ & PTDI values for a body weight of $90 \mathrm{~kg}$ \\
\hline & $P T D I$ & PTDI \\
\hline$A l$ & $16 \mathrm{mg} \mathrm{l}^{-1}$ & $24 \mathrm{mg} \mathrm{l}^{-1}$ \\
\hline As & & \\
\hline Cd & $50 \mu \mathrm{g} \mathrm{l}^{-1}$ & $75 \mu \mathrm{g} \mathrm{l}^{-1}$ \\
\hline $\mathrm{Cu}$ & $30 \mathrm{mg} \mathrm{l}^{-1}$ & $45 \mathrm{mg} \mathrm{l}^{-1}$ \\
\hline Fe & $48 \mu \mathrm{g}^{-1}$ & $72 \mu \mathrm{g} \mathrm{l}^{-1}$ \\
\hline$P b$ & & \\
\hline$Z n$ & $18-60 \mathrm{mg} \mathrm{l}^{-1}$ & $27-90 \mathrm{mg} \mathrm{l}^{-1}$ \\
\hline
\end{tabular}

Table 6 Element content of a glass of beer $(0,51)$

\begin{tabular}{|c|c|c|c|c|c|}
\hline \multirow{2}{*}{ Sample } & \multicolumn{5}{|c|}{ Concentration } \\
\hline & $A l\left(m g l^{-1}\right)$ & $A s\left(\mu g l^{-1}\right)$ & $C u\left(m g l^{-1}\right)$ & $P b\left(\mu g l^{-1}\right)$ & $Z n\left(m g l^{-1}\right)$ \\
\hline 1 & 0.035 & 5.10 & 0.043 & 3.01 & 0.024 \\
\hline 2 & 0.077 & 2.63 & 0.035 & 1.99 & 0.015 \\
\hline 3 & 0.036 & 1.50 & 0.047 & 2.43 & 0.012 \\
\hline 4 & & 1.40 & 0.042 & 2.07 & 0.015 \\
\hline 5 & & 1.22 & 0.048 & 2.19 & 0.014 \\
\hline 6 & & 2.34 & 0.046 & 1.93 & 0.012 \\
\hline 7 & & 2.65 & 0.055 & 2.85 & 0.015 \\
\hline 8 & 0.046 & 1.75 & 0.050 & 2.20 & 0.032 \\
\hline 9 & & 2.10 & 0.050 & 2.49 & 0.014 \\
\hline 10 & & 2.40 & 0.031 & 2.36 & 0.027 \\
\hline 11 & & 1.32 & 0.042 & 2.89 & 0.023 \\
\hline 12 & 0.075 & 1.59 & 0.053 & 2.69 & 0.037 \\
\hline 13 & & 1.59 & 0.038 & 2.30 & 0.049 \\
\hline 14 & 0.080 & 2.92 & 0.049 & 2.49 & 0.017 \\
\hline 15 & 0.093 & 2.04 & 0.049 & 2.47 & 0.051 \\
\hline 16 & 0.223 & 2.09 & 0.047 & 2.31 & 0.020 \\
\hline 17 & & 1.37 & 0.048 & 2.49 & 0.025 \\
\hline 18 & & 1.05 & 0.035 & 1.95 & 0.034 \\
\hline 19 & & 1.63 & 0.014 & & 0.023 \\
\hline 20 & & 0.98 & 0.029 & & 0.022 \\
\hline 21 & & 0.91 & 0.024 & & 0.040 \\
\hline 22 & & 1.62 & 0.026 & & 0.036 \\
\hline 23 & & 4.16 & 0.042 & 2.12 & 0.019 \\
\hline 24 & & 1.96 & 0.036 & & 0.023 \\
\hline
\end{tabular}

In the knowledge of the samples element concentrations and PTDI values, a risk assessment can be carried out to determine whether these samples could have an adverse effect on human health or not. Final results of the risk assessment are presented in Table 7, for consumers with a body weight of 60 and $90 \mathrm{~kg}$. Risk assessment has only been performed for $\mathrm{Al}, \mathrm{Cu}$ and $\mathrm{Zn}$, because PTI values had been withdrawn for $\mathrm{As}$ and $\mathrm{Pb}$, and $\mathrm{Cd}$ and $\mathrm{Fe}$ concentrations were lower than
LoD in each sample, this is why no risk could appear because of these elements. As Table 7 presents, none of the elements could be found in the analysed samples in a concentration which could mean a potential hazard to the consumers - the calculated values of risks were higher than 10 by all samples.

Table 7 Final results of risk assessment for 60 and $90 \mathrm{~kg}$ bw

\begin{tabular}{|c|c|c|c|c|c|c|c|c|}
\hline \multirow{3}{*}{ Sample } & \multicolumn{8}{|c|}{ Risk } \\
\hline & \multicolumn{4}{|c|}{$60 \mathrm{~kg} \mathrm{bw}$} & \multicolumn{4}{|c|}{$90 \mathrm{~kg} \mathrm{bw}$} \\
\hline & $A l$ & $C u$ & Zn 18 & Zn 60 & $A l$ & $C u$ & Zn 27 & Zn 90 \\
\hline 1 & 457 & 698 & 740 & 2467 & 686 & 1047 & 1110 & 3700 \\
\hline 2 & 209 & 857 & 1188 & 3960 & 314 & 1286 & 1782 & 5941 \\
\hline 3 & 444 & 638 & 1488 & 4959 & 667 & 957 & 2231 & 7438 \\
\hline 4 & & 723 & 1241 & 4138 & & 1084 & 1862 & 6207 \\
\hline 5 & & 625 & 1274 & 4248 & & 938 & 1912 & 6372 \\
\hline 6 & & 659 & 1500 & 5000 & & 989 & 2250 & 7500 \\
\hline 7 & & 550 & 1241 & 4138 & & 826 & 1862 & 6207 \\
\hline 8 & 348 & 606 & 563 & 1875 & 522 & 909 & 844 & 2813 \\
\hline 9 & & 600 & 1286 & 4286 & & 900 & 1929 & 6429 \\
\hline 10 & & 968 & 667 & 2222 & & 1452 & 1000 & 3333 \\
\hline 11 & & 714 & 783 & 2609 & & 1071 & 1174 & 3913 \\
\hline 12 & 427 & 566 & 486 & 1622 & 640 & 849 & 730 & 2432 \\
\hline
\end{tabular}




\begin{tabular}{|c|c|c|c|c|c|c|c|c|}
\hline 13 & & 789 & 367 & 1224 & & 1184 & 551 & 1837 \\
\hline 14 & 400 & 619 & 1059 & 3529 & 600 & 928 & 1588 & 5294 \\
\hline 15 & 344 & 612 & 356 & 1188 & 516 & 918 & 535 & 1782 \\
\hline 16 & 143 & 638 & 923 & 3077 & 215 & 957 & 1385 & 4615 \\
\hline 17 & & 625 & 720 & 2400 & & 938 & 1080 & 3600 \\
\hline 18 & & 857 & 537 & 1791 & & 1286 & 806 & 2687 \\
\hline 19 & & 2222 & 800 & 2667 & & 3333 & 1200 & 4000 \\
\hline 20 & & 1053 & 818 & 2727 & & 1579 & 1227 & 4091 \\
\hline 21 & & 1277 & 456 & 1519 & & 1915 & 684 & 2278 \\
\hline 22 & & 1176 & 500 & 1667 & & 1765 & 750 & 2500 \\
\hline 23 & & 714 & 947 & 3158 & & 1071 & 1421 & 4737 \\
\hline 24 & & 833 & 800 & 2667 & & 1250 & 1200 & 4000 \\
\hline
\end{tabular}

\section{CONCLUSION}

In this study, the micro and trace element contents of 24 beer samples with different origin have been measured to search for relations between beer types and element concentrations. The results of the measurements could be attributable to many factors, such as the species and subspecies of the raw materials used, soil properties, agricultural technologies. Besides the influencing factors of raw materials, water usage and water treatment during the production could also be a key point in the production of the characteristics.

According to the statistical analysis, the differentiation of these four types could be possible by the determination of microelement contents, but to establish that, further investigations are necessary with a higher sample number.

After a risk assessment has been carried out, it appeared that consuming beer in a temperate quantity could not have any adverse effect as regard the toxic element concentrations, because none of these elements were present in the analysed samples in a hazardous concentration.

Acknowledgements: This publication is supported by the EFOP-3.6.3-VEKOP16-2017-00008 project. The project is co-financed by the European Union and the European Social Fund.

\section{REFERENCES}

Alcázar, A., Pablos, F., Martín, J., González, A.G., (2002). Multivariate characterisation of beers according to their mineral content. Talanta, 57, 45-52. https://doi.org/10.1016/S0039-9140(01)00670-1

Donadini, G., Spalla, S., Beone, G.M., (2008). Arsenic, Cadmium and Lead in Beers from the Italian Market. Journal of the Institute of Brewing, 114, 283-288. https://doi.org/10.1002/j.2050-0416.2008.tb00770.x

FAO (2009). Malt, barley, beer. Agribusiness handbook. Rome, Italy.

Gama, E.M., Nascentes, C.C., Matos, R.P., Rodrigues, G.C., Rodrigues, G.,

(2017). A simple method for the multi-elemental analysis of beer using total reflection X-ray fluorescence. Talanta, 174, 274-278 https://doi.org/10.1016/j.talanta.2017.05.059

Kovács, B., Győri, Z., Csapó, J., Loch, J., Dániel, P., (1996). A study of plant sample preparation and inductively coupled plasma emission spectrometry parameters. Communications in Soil Science and Plant Analysis, 27 (5-8), 1177 1198. https://doi.org/10.1080/00103629609369625

Mena, C., Cabrera, C., Lorenzo, M.L., López, M.C., (1996). Cadmium levels in wine, beer and other alcoholic beverages: possible sources of contamination. The Science of the Total Environment, 181, 201-208. https://doi.org/10.1016/00489697(95)05010-8

Pascari, X., Ramos, A.J., Marín, S., Sanchís, V., (2018). Mycotoxins and beer. Impact of beer production process on mycotoxin contamination. A review. Food Research International, $103, \quad 121-129$. https://doi.org/10.1016/j.foodres.2017.07.038

Vecseri, B., (2004). Az ásványi anyag tartalom tanulmányozása a sörgyártás műveleti lépései során. Doktori értekezés. Budapest, 2004.

WHO (1982). Evaluation of certain food additives and contaminants: Twenty-six report of the Joint FAO/WHO Expert Committee on Food Additives. WHO technical report series no. 683. Geneva, Switzerland.

WHO (1983). Evaluation of certain food additives and contaminants: Twentyseventh report of the Joint FAO/WHO Expert Committee on Food Additives. WHO technical report series no. 696. Geneva, Switzerland.

WHO (2010). Evaluation of certain food additives and contaminants: Seventysecond report of the Joint FAO/WHO Expert Committee on Food Additives. WHO technical report series no. 959. Rome, Italy.

WHO (2010). Evaluation of certain food additives and contaminants: Seventythird report of the Joint FAO/WHO Expert Committee on Food Additives. WHO technical report series no. 960. Rome, Italy.
WHO (2011). Evaluation of certain food additives and contaminants: Seventyfourth report of the Joint FAO/WHO Expert Committee on Food Additives. WHO technical report series no. 966. Rome, Italy.

WHO (2013). Evaluation of certain food additives and contaminants: Seventyseventh report of the Joint FAO/WHO Expert Committee on Food Additives. WHO technical report series no. 983. Rome, Italy. 